\title{
Makunaima e Macunaíma. Entre a natureza e a história
}

Daniel Faria

Pós-doutorando, Departamento de História, UNICAMP

\section{RESUMO}

Este artigo tem como tema central a questão do desejo romântico pela natureza como resposta a conflitos políticos contemporâneos. Tomando alguns exemplos da década de 1920 no Brasil, discuto a maneira como Macunaíma, de Mário de Andrade, constituiu-se como projeção de um espaço natural prévio a toda historicidade. Em contraste, apresento o ambiente extremamente conflituoso em que Koch-Grünberg coletou relatos indígenas sobre Makunaima. A natureza estetizada inventada pelo romantismo teve como efeito o encobrimento da violência constitutiva daquilo que ainda hoje se entende como a realidade nacional.

Palavras-chave: Macunaima; Romantismo; Natureza.

\section{ABSTRACT}

This text has as its central theme the romantic desire for nature as a response to the contemporary political conflicts. Taking some examples from the 1920's, I discuss the way Macunaima, a work of Mário de Andrade, was based on an image of a natural space without any history. By contrast, I present the extremely conflictuous area in which Koch-Grünberg has collected the narratives about Makunaima. The aestheticized nature invented by the romantics had as its result the covering of the violence constitutive of what indeed today is understood as national reality.

Keywords: Macunaíma; Romanticism; Nature.

O Manifesto Pau-Brasil, assinado por Oswald de Andrade, foi prefaciado por Paulo Prado em maio de $1924 .{ }^{1}$ Nesse texto, o prefaciador exaltava a originalidade da estética pau-brasil, como afirmação do nacionalismo que poria fim à dependência brasileira com relação a uma Europa "decadente e esgotada".

Oswald de Andrade, numa viagem a Paris, do alto de um atelier da Place Clichy — umbigo do mundo - descobriu, deslumbrado, a sua própria terra. A volta à pátria confirmou, no encantamento das descobertas manuelinas, a 
revelação surpreendente de que o Brasil existia. Esse fato, de que alguns já desconfiavam, abriu seus olhos à visão radiosa de um mundo novo, inexplorado e misterioso.

A redescoberta da brasilidade, ainda de acordo com Paulo Prado, ocorrera em luta contra uma tradição de idéias importadas, livrescas. Estas teriam ocultado a autenticidade do "ritmo profundo da raça". Portanto, a viagem à Europa empreendida por Oswald tinha, nesse texto, também um sentido metafórico: Europa significava uma tradição em decadência, que precisava ser suplantada pela instauração do princípio nacional, ou pelo reconhecimento de sua força regeneradora. Neste sentido, a construção da idéia de redescoberta da brasilidade se dava sob a imagem do retorno, da volta às origens, que, de acordo com a construção de Paulo Prado, teriam sido abandonadas em virtude dos mantos artificiais da civilização ocidental. A idéia de Europa remetia aos excessos de civilização e história, em contraste com o Novo Mundo e sua natureza ainda virgem.

A associação entre viagem, como no caso do Manifesto Pau-brasil, e construção do sentido nacional como oposição entre natureza e história não era novidade na tradição intelectual moderna. ${ }^{2}$ Aproximadamente um século antes do périplo de Oswald e Paulo Prado, o movimento romântico havia sido fundado numa narrativa semelhante. Gonçalves de Magalhães foi à Europa em 1833, onde teria entrado em contato com a literatura francesa, e de onde, segundo Antonio Candido, ${ }^{3}$ traria a nova literatura brasileira. Daí, a publicação da obra considerada como inaugural do romantismo brasileiro, Suspiros poéticos e saudades. Viagens como essas indicam que a encenação da descoberta da força da natureza tropical exigia um momento de distanciamento, como se somente em meio ao fardo da história experimentado na Europa a natureza se revelasse em seu esplendor. Descoberta aqui no sentido da capacidade de apreensão estética dos princípios tidos como fundamentais daquela natureza - e não é ocioso lembrar que desde o romantismo, pelo menos, a obra de arte foi inscrita nesse horizonte de naturalidade reconquistada. Daí também que essas viagens, organizadas por categorias estéticas, reduplicassem aquilo que outros viajantes já haviam dito. ${ }^{4}$ Como se a natureza só pudesse ser imaginada por alguém que estivesse do lado de fora. Neste sentido, mais do que o encontro com o outro lugar que se visitava, a viagem romântica era desenhada como possibilidade de se recuperar aquilo que se perdera durante a partida.

Ainda de acordo com Antonio Candido, a experiência da viagem transfiguradora foi comum aos grandes românticos: Goethe, Chateaubriand, Keats, 
Byron e Wordsworth, entre outros. A viagem romântica, naquele contexto, era entendida como a possibilidade de saída do cotidiano, com a redescoberta de suas facetas misteriosas e o reencontro com as fontes mais profundas da subjetividade. Tratava-se, portanto, de uma aventura rumo ao transcendental, de experiências que levariam ao encontro com as origens mesmas da existência humana. O mundo da cultura, da civilização, da história era então imaginado como uma prisão, face à natureza que se apresentava como constante genialidade criadora.

Nesse mesmo sentido, em 1926 surgiu o livro Pathé-Baby de Antônio de Alcântara Machado. ${ }^{5}$ Pathé-Baby não foi escrito, propriamente, como romance, mas roteiro de viagens. O itinerário descrito pelo autor em Pathé-Babyé indicativo do tom cosmopolita do livro: Las Palmas, Lisboa, Paris, Milão, Londres, Florença, Roma, Barcelona, Madri, dentre outras cidades européias. Antônio de Alcântara Machado fez, assim, uma espécie de mapa ficcional da Europa moderna. A linguagem da obra trazia os padrões correntemente assinalados à estética literária do modernismo: síntese, ironia e cortes "cinematográficos".

Mas o aspecto a ser ressaltado aqui é a configuração do espaço narrativo, da viagem que vai traçando e moldando significados. À medida que o narrador viajava pela Europa, o continente ia ganhando forma textual. As grandes cidades européias, na escrita de Pathé-Baby, eram ocupadas por personagens e objetos descritos em sua superficialidade, em encontros repentinos e passageiros. Mesmo aquelas cidades menos modernizadas, como Toledo e Assis, foram configuradas como o espaço onde fantasmas apareciam, encantavam a visão e desapareciam. Para exemplificar:

Das janelas da torre, os telhados das casas são papoulas crescidas na paisagem verde. Ladeiras de musgo e frescura. O sino da igrejinha pula de contente. $\mathrm{Na}$ fonte, a mulher de saia enrolada na cintura inclina o cântaro amarelo. O velhote acocorocado no banco de pedra sorri para as moscas. Um cachorro coça a orelha. Zangado. O moreno, de guitarra sob o braço, pára para acender o cigarro. Sombra.

A superficialidade da narrativa devia-se, em parte, ao teor descritivo da obra. Mas também projetava, sobre o mundo moderno, a imagem de civilização dominada pelas relações abstratas e pelo mecanicismo, construída pelos românticos para o mundo contemporâneo. As personagens da viagem de Alcântara Machado não expressavam sentimentos ou crenças, limitando-se a 
serem aparências destituídas de profundidade psicológica. Assim, a Europa era narrada como um mundo "sem alma". Em quase todas as cidades surgia a figura fantasmática de um inglês endinheirado, apareciam as luzes piscantes da publicidade, com a transformação de monumentos e obras de arte em objetos negociáveis. Todos os valores se reduziam à possibilidade da troca. Superficialidade que também tinha conotações políticas. Em Paris, em meio ao brilho de uma cidade festiva, repentinamente, surgiu um bêbado cantando a Internacional Socialista. Nas cidades italianas, freqüentemente um camisapreta fascista era visto. O texto de Alcântara Machado não escondia as tensões políticas de seu tempo. Contudo, ao fim do itinerário, a Europa parecia ser um continente encantador, mas destituído de densidade afetiva. Mesmo as alternativas revolucionárias pareciam embotadas, num continente que se limitara às superficialidades da cultura.

$\mathrm{O}$ autor deu ainda algumas indicações do que ele consideraria uma possível alternativa a esse universo isento de expressões de subjetividade. Na França, Alcântara Machado fez a única menção ao sentimento de saudade que o invadia; saudade de sua terra, o Brasil. Esse, também, foi no livro um dos raros momentos em que a narrativa abandonou a superficialidade descritiva, alcançando algo de vida psíquica e sentimental do narrador. E, mais importante ainda, ao fim do itinerário, o narrador deixou como "Moralidade" a citação de um trecho de poema de Gonçalves Dias:

Nosso céu tem mais estrelas,

Nossas várzeas têm mais flores,

Nossos bosques têm mais vida,

Nossa vida mais amores.

A. Gonçalves Dias, “Canção do Exílio”.

Na última página indicava-se que o livro havia sido impresso em 1926, pela editorial Helios, " "desta cidade de São Paulo”. As três referências indicavam que a alternativa para a crise do mundo contemporâneo, como época de desenraizamento e exílio, estaria no contraponto da brasilidade. A construção de um novo mundo não se daria nas camisas pretas do fascismo, muito menos nas cantigas insolentes de um bêbado. O relato de Alcântara Machado desembocava na postulação da saída pela via da nacionalidade, única instância narrativa onde o autor, seus sentimentos mais profundos e a realidade objetiva formavam um todo harmonioso. A nacionalidade surgia, assim, como 
princípio estético-político, ponto de partida e de chegada das viagens narradas. A referência a Gonçalves Dias tinha certo teor irônico, mas não satírico ou paródico. Na Europa, o sentimento da saudade surgia como motivação de um retorno ao romantismo, à celebração da natureza, da vida e do amor.

Roteiros de viagem em que a natureza era o alvo, em contraponto à civilização, não foram raros nos anos 20. Em carta de 6 de abril de 1927, Mário de Andrade anunciava a Manuel Bandeira sua intenção de viajar pelo norte do Brasil. ${ }^{7}$ A viagem de Mário estava inscrita em seus principais projetos intelectuais, com a coleta de informações sobre a cultura popular, na busca de uma suposta essência da brasilidade. Mário de Andrade partiu a 7 de maio daquele ano, acompanhado de Dona Olívia Guedes Penteado, sua sobrinha e a filha de Tarsila do Amaral. Durante a viagem, o poeta paulista planejou a escrita de um livro onde suas experiências seriam relatadas, dando ao público do sul a chance de conhecer o Brasil supostamente esquecido. Daí a riqueza das descrições dos diários da viagem:

A foz do Amazonas é uma dessas grandezas tão grandiosas que ultrapassam as percepções fisiológicas do homem. Nós só podemos monumentalizá-las na inteligência. O que a retina bota na consciência é apenas um mundo de águas sujas e um matinho sempre igual no longe mal percebido das ilhas. O Amazonas prova definitivamente que a monotonia é um dos elementos mais grandiosos do sublime. É incontestável que Dante e o Amazonas são igualmente monótonos. Pra gente gozar um bocado e perceber a variedade que tem nessas monotonias do sublime carece limitar em molduras mirins a sensação ${ }^{8}$

Em diversos momentos de seu itinerário, como no caso citado, Mário de Andrade fez referência ao caráter sublime da natureza amazônica, recorrendo assim a uma categoria estética já bem delineada pelo romantismo. A imponência construída nas descrições da natureza tropical resultava no desafio constante da descrição. Estando em Salvador a 13 de maio de 1927, Mário de Andrade falou da relação tensa entre suas experiências de viajante e o ofício de escritor. Isto porque os qualificativos disponíveis para a descrição, tais como 'maravilhoso,' 'manhã sublime', 'moça linda', sempre estariam aquém dos acontecimentos concretos narrados. Já no Rio Madeira, a 3 de julho, Mário expressou a mesma indizibilidade do mundo natural, referindo-se então ao crepúsculo, que "dava vontade de gritar, de morrer de amor, de esquecer tudo”. O mundo amazônico propiciaria, na narrativa da viagem de Mário, o 
reencontro com as potências estéticas do mundo - o que faria do norte do país o espaço do maravilhoso, regido por leis diversas das do mundo cotidiano.

De acordo com o diário de viagem, na noite de 3 de junho Mário de Andrade sonhou com uma cidade encantada, Itacoatiara. A cidade tinha setecentos palácios triangulares de granito, com uma única porta vermelha. Itacoatiara era composta por ruas líquidas, nas quais o modo de locomoção era o peixe-boi, para os homens, e o boto, para as mulheres. Um grupo de belas moças, vestidas de encarnado, teria levado Mário a um palácio repleto de redes de ouro e prata. Depois, Mário e as moças teriam ido aos monumentos públicos, ali fazendo amor, despreocupados em relação aos burocratas, uma vez que estes se ocupavam com outros assuntos. As ruas da cidade tinham nomes idílicos, como rua do Meu Bem, rua da Rainha do Café e rua das Meninas. Quando Mário estava cortando os cabelos das moças lindas, alguém o teria acordado, interrompendo o sonho.

A oposição entre a Itacoatiara sonhada e a São Paulo como lugar de civilização, em Mário de Andrade, dava-se em termos bastante semelhantes aos do debate alemão dos anos 20 sobre Kultur e Zivilisation. De acordo com Jeffrey Herf, ${ }^{9}$ esses dois conceitos estabeleciam uma oposição fundamental para a linguagem do modernismo reacionário, de autores como Oswald Spengler e Ernst Jünger. Naquele debate, o termo "cultura" era identificado com o povo, o sangue, a tradição e a raça, o substrato do que se considerava ser a germanidade - numa relação de proximidade semântica à natureza. Ao passo que "civilização" indicava o mundo das máquinas, do progresso, do materialismo, do liberalismo e da vida política da República de Weimar. O desafio que os modernistas reacionários alemães propunham solucionar, de acordo com Jeffrey Herf, era o de que a "civilização" fosse incorporada pela "cultura", instaurando-se, assim, uma modernidade calcada nos valores da "raça germânica".

É importante observar que os conceitos de civilização e cultura, inspirados na tradição romântica, não eram estranhos a Mário de Andrade. Ao contrário, de acordo com uma referência em carta de Manuel Bandeira, aquele binômio era uma das lentes usadas por Mário na interpretação do mundo contemporâneo. ${ }^{10}$ Assim, a Itacoatiara do sonho de Mário de Andrade era uma cidade utópica, no sentido de que punha fim aos conflitos políticos, às limitações mundanas, sendo a concretização dos anseios estéticos do autor. Esteticamente, a cidade encantada despertava as mesmas sensações que a beleza sublime da natureza amazônica. Em Itacoatiara o mundo natural, o social e o político estavam harmonizados. Neste sentido, tratava-se de uma cidade su- 
blime, romântica, onde a cultura e a natureza se revelaram como alternativa à civilização.

Na procura da brasilidade "autêntica", a viagem de Mário de Andrade ao norte do Brasil foi narrada como a procura de concretização de utopias. Neste sentido, vale também citar o caso da tribo Dó-Mi-Sol, inventada pelo autor durante o itinerário, com uma intenção satírica. Esta, segundo Mário, caracterizava-se principalmente pelo fato de seus integrantes não recorrerem a palavras para se comunicarem, mas a sons musicais. Além disso, seu vocabulário estava repleto de denominações para o mal, em todas suas gradações. Destas, a mais apreciada era a "principiada num som grave e atingindo a quinta superior", que designaria a palavra 'inimigo. ${ }^{11}$ Os atos bondosos recebiam apenas uma designação genérica. Tal situação faria os índios Dó-Mi-Sol serem "progressistas e conformados", nas palavras do autor. Outro aspecto da tribo inventada por Mário de Andrade era a preguiça totêmica, que os teria levado à consciência profunda do movimento, uma vez que, neles, cada gesto mínimo ganharia intensidade psíquica.

Em contraposição às vivências utópicas de Mário, na região por ele tida como incivilizada, o norte do Brasil também serviria de mote para críticas concretas à organização política do país, nos anos 20. O mercado de Belém era o exemplo da beleza inaproveitada, em virtude da "desorganização nacional”. Mas o problema mais grave, de acordo com Mário, referia-se ao mau aproveitamento da borracha. Que se tornou, para o autor, metáfora da situação do Brasil, com suas elites semicultas, maleáveis e inconsistentes. Numa de suas primeiras notas, a 18 de maio, Mário de Andrade acusou o Brasil de ter se perdido numa opção civilizacional superficial, marcada pelo mimetismo com relação à Europa e, por isso, impossibilitado de criar um mundo próprio. ${ }^{12}$ Mundo próprio que, ao que indicava o diário de viagem, estava oculto na natureza.

Nas viagens de Mário pelo norte e nordeste do Brasil, assuntos estéticos, políticos, literários e científicos estavam relacionados. Configurando, assim, mais uma vez, uma proposta civilizacional. O primitivo, que se consubstanciara na imagem mágica da natureza do norte, era, em Mário de Andrade, uma promessa de possível redenção para o mundo contemporâneo. Assim, em carta a Manuel Bandeira, a 28 de março de 1931, Mário falou de sua concepção sobre a "mentalidade primitiva", baseada nas obras do antropólogo Tylor, consabidamente evolucionista. Naquela mentalidade, a inatividade física e a preguiça dariam materialidade às funções intelectuais, o que faria dos objetos do mundo exterior forças mágicas. Estas considerações, ainda segun- 
do Mário de Andrade, faziam parte de um projeto de criação de uma civilização onde a paciência e a preguiça pusessem fim às dores e aos prazeres. Aqui se explicitando a equivalência já pressuposta nos diários de viagem, entre os indígenas e a natureza - analisados sob o prisma de categorias estéticas modernas e de acordo com os parâmetros evolucionistas que estabeleciam uma clara diferença entre "primitivos" e "civilizados".

Tais considerações remetem à obra central de Mário de Andrade, Macunaíma, o herói sem nenhum caráter. Livro fundamental da tradição modernista, publicado em 1928, foi intensamente elogiado por críticos, tanto por se tratar de uma das prosas mais bem acabadas da literatura brasileira, como por se inscrever no quadro das tentativas de simbolização-invenção da identidade nacional. ${ }^{13}$ Vale notar que vários aspectos da obra foram construídos a partir das viagens do autor pelo norte do país, em suas coletas de lendas e mitos da "mentalidade primitiva".

O que se expressou, sobretudo, na descrição da terra natal de Macunaíma, o "fundo do mato-virgem". Espaço de metamorfoses, de seres encantados, onde Macunaíma preparava suas artimanhas, motivadas, sobretudo, pela indolência e pelo erotismo. Nos primeiros capítulos da rapsódia de Mário de Andrade, o protagonista enfrentaria monstros da mitologia indígena, como o Curupira, e, depois de algumas peripécias, encontraria Ci, a Mãe do Mato. Esta faria de Macunaíma o Imperador da região e lhe daria a pedra verde sagrada, a muiraquitã. Desta forma, a configuração do espaço narrativo de Macunaíma levava à construção de metáforas indicativas de uma vida primitiva, originária.

Contudo, a configuração da personagem Macunaíma não terminava aí. Numa de suas aventuras, o herói acabou perdendo sua pedra sagrada. Com isso, Macunaíma tentou reavê-la, descobrindo que ela estava em posse de Venceslau Pietro Pietra, um fazendeiro de São Paulo. A partir daí, Macunaíma se tornou um viajante. $\mathrm{O}$ abandono de sua terra natal significou a necessidade do enfrentamento com a vida civilizada, numa grande metrópole. Chegando a este espaço, a narrativa de Mário adquiria outros sentidos, calcados no confronto entre a modernidade paulista e a mentalidade mágica de Macunaíma. Configurando, também, o espaço dos confrontos com Venceslau, identificado pelos hábitos alimentares e pelo linguajar com a figura do imigrante ítalopaulista. Desta forma, significativamente, ao ser derrotado por Macunaíma, Venceslau morreria afogado numa imensa panela de macarronada fervente. ${ }^{14}$

Depois de recuperada a muiraquitã, vinha a terceira etapa das viagens de Macunaíma: a volta ao mato-virgem. Porém, no retorno do herói a terra en- 
cantada estava transformada, o encantamento tinha sido solapado. Em lugar dos antigos seres mitológicos, o que predomina na terceira parte da narrativa é a desolação, a fome e a doença. O impaludismo e a lepra assolavam a região, que se tornara quase inabitada. $\mathrm{O}$ antigo mato-virgem se transformara num deserto, onde Macunaíma viveria solitário e melancólico. Ali, o herói ainda perderia definitivamente a muiraquitã, antes de se cansar da vida nesta terra, indo aos céus, onde se transformaria na constelação da Ursa Maior. As viagens de Macunaíma tiveram, portanto, o aspecto de uma perda, do desencantamento do mundo, significado, metaforicamente, pelo desaparecimento da pedra verde, mas sobretudo pela destruição da pujança natural do mato virgem.

Mário de Andrade, nos prefácios ${ }^{15}$ a Macunaíma, que acabaram não sendo publicados juntamente com o livro, indicou o sentido que a rapsódia teria para ele. Em primeiro lugar, o autor procurava ressaltar o caráter literário de seu livro. Com isso, Macunaíma não deveria ser lido como um tratado sociológico, mas como invenção livre de um enredo narrativo. À parte isto, Mário de Andrade também ressaltou o fato de que o livro seria um índice da "entidade nacional dos brasileiros", uma súmula de seu caráter psicológico. Advertindo para o fato de que Macunaíma não era um símbolo da psiqué brasileira, Mário defendia uma leitura que entendesse sua obra como um "sintoma" da brasilidade. Portanto, o livro era, simultaneamente, invenção literária, resultado de pesquisas etnográficas e ponto de partida para uma reflexão sobre a brasilidade. De acordo com o autor,

Um dos meus interesses foi desrespeitar lendariamente a geografia e a fauna e a flora geográficas. Assim desregionalizava o mais possível a criação ao mesmo tempo que conseguia o mérito de conceber literariamente o Brasil como entidade homogênea um conceito étnico nacional geográfico. ${ }^{16}$

A configuração do espaço narrativo de Macunaíma, portanto, obedecia ao projeto de construção de uma imaginação geográfica. E é nesta questão que se vislumbra o alcance político da obra de Mário. A intensa mobilidade de Macunaíma pelo espaço narrativo, de acordo com Mário, representava a conquista da totalidade da geografia nacional. ${ }^{17}$ Assim, naquela rapsódia, a brasilidade ganhava a dimensão de essência delimitadora das fronteiras do país, garantindo, ao mesmo tempo, sua unidade. Ao que a obra indicava, porém, essa unidade funcionava mais como anseio estético e político, uma vez que a nação se via dilacerada, entre a civilização e a natureza. Saindo de um espaço de indistinção entre os seres, de harmonia e de inexistência do desentendi- 
mento político, o herói Macunaíma fazia um percurso rumo à civilização representada como potência do caos, do conflito e da morte.

A natureza apresentada no início da rapsódia de Mário de Andrade era, assim, uma espécie de resposta aos dilemas políticos de seu tempo. Tanto quanto o Novo Mundo supostamente redescoberto por Oswald de Andrade e Paulo Prado, ou o Brasil vislumbrado por Alcântara Machado, o mato-virgem de Macunaima era assim uma invenção feita a partir da e na civilização. Uma projeção cultural dirigida aos embates políticos do mundo contemporâneo. Seguindo Clement Rosset, ${ }^{18}$ podemos dizer que, de fato, a idéia romântica da natureza seria mais bem entendida como um desejo de natureza, no sentido de que além de estabelecer um conjunto de imagens, a naturalidade romântica aparecia como meta, sonho, projeto de pessoas que se viam aprisionadas pela civilização e pela história.

Ainda nesse sentido, note-se que os indígenas eram tratados como uma das variações temáticas da música da natureza, mas não eram, evidentemente, os leitores almejados pela rapsódia de Mário. O público leitor certamente não residia no mato virgem.

\section{HiSTÓRIAS QUE A NATUREZA ESCONDE}

Um pouco mais de atenção ao começo de Macunaíma:

No fundo do mato-virgem nasceu Macunaíma, herói de nossa gente. Era preto retinto e filho do medo da noite. Houve um momento em que o silêncio foi tão grande escutando o murmurejo do Uraricoera, que a índia tapanhumas pariu uma criança feia. Essa criança é que chamaram de Macunaíma.

O herói de nossa gente nasceu num tempo e espaço não-históricos: é filho de uma noite absoluta. Não pertencendo a uma tradição qualquer, tem com seu nascimento um começo, uma origem também significada pela ausência do Pai. Antes da perda da muiraquitã, é nesse tempo mítico que se darão suas aventuras. Tempo que se complementa num espaço geográfico indefinido, como o demonstram topônimos como "Canfundó dos Judas", "estrada dos Prazeres", "cidade das Flores", usados para caracterizar o mato virgem e que trazem à memória os nomes das ruas da sublime Itacoatiara. Estas marcas configuram, na rapsódia, um ambiente para a recorrência de alguns temas narrativos que traçam as disposições morais do herói e seus irmãos, mas não correspondem propriamente a experiências, no sentido de um aprendi- 
zado adquirido com os reveses da vida. Experiências virão apenas com a viagem de Macunaíma a São Paulo, momento em que a rapsódia quase se torna um romance de formação. Quase, porque uma das características permanentes do herói (muito bem caracterizado desde o começo da narrativa) é exatamente uma espécie de recusa ao aprendizado. Característica elogiosa apenas numa leitura feita num viés mais antropófago, mas jamais do ponto de vista do pedagogo Mário de Andrade. ${ }^{19}$

Porém, a própria narrativa traz alguns índices de algo não totalmente recoberto por essa natureza originária, esse espaço a-histórico, apresentando vestígios de uma tradição não literária. Por exemplo, sabemos que no estado de Roraima existe um rio também chamado Uraricoera. Coincidência não meramente fortuita, pois outro dado consabido é o fato de a rapsódia de Mário de Andrade ter sido inspirada na leitura do relato etnográfico de Koch-Grünberg, antropólogo alemão que esteve entre o monte Roraima e o médio Orinoco entre 1911 e 1913, onde obteve os relatos sobre Makunaima. ${ }^{20}$ Ainda neste aspecto, vale ressaltar que um dos tópicos mais comemorados de Macunaíma, o herói sem nenhum caráter, é exatamente o diálogo com textos etnográficos, sociológicos e literários. Os dois primeiros tipos de discurso, ao menos, conferiram à narrativa uma inegável aura de veracidade, por indicarem o fato de a obra de Mário de Andrade corresponder a profundos estudos sobre a condição nacional e por emprestarem à rapsódia o poder de verdade geralmente atribuído às narrativas míticas. O Uraricoera da obra literária tirou assim um suplemento de força persuasiva por ser um tipo de vestígio do Uraricoera de Roraima. E o mesmo pode ser dito quanto ao próprio Macunaíma, em evidente estado de comunicação com o Makunaima apresentado a Koch-Grünberg ${ }^{21}$ por dois narradores, Akúli, índio arekuná, e Mayuluaípu, índio taulepangue.

Muito da riqueza literária de Macunaíma vem sem dúvida desse tipo de ambigüidade, entre a invenção literária e a pesquisa científica, entre a criação lúdica e a interpretação da suposta realidade nacional, e a proposta deste artigo não é substituir a tessitura de um texto complexo por uma leitura mais simplista. O que está em jogo é a relação da obra com interpretações cristalizadas, desde o romantismo, que jogam a singularidade da nação na imagem estetizada de sua natureza. Narrada como uma viagem em sentido contrário à maioria dos périplos românticos, estes indo da civilização à natureza, a rapsódia de Mário de Andrade nem por isso se torna um relato originário, vindo diretamente do mato virgem.

Então, seguindo os índices que deram à obra de Mário de Andrade grande eficácia extra-literária, já no final da rapsódia, diante do mato virgem des- 
truído pela ação deletéria da civilização, Macunaíma lembra que "na terra dos ingleses" havia milho. A expressão "terra dos ingleses" também estava presente no relato de Koch-Grünberg. Fora usada por um dos narradores indígenas, e é claramente vestígio de uma longa disputa territorial conformadora das relações políticas e culturais na grande região que engloba o Uraricoera. Disputa que remonta ao século XVII, e que permanece ainda hoje latente nos debates sobre a demarcação da área da Raposa/Serra do Sol (esta já mais próxima à fronteira com a Guiana).

Nádia Farage ${ }^{22}$ mostrou toda a dramaticidade da constituição do território nacional no espaço que abrange o rio Uraricoera, que se deu entre guerras, aldeamentos forçados e escravizações até o século XVIII. Depois, com a tentativa frustrada de transformar os diversos povos indígenas da região da bacia do rio Branco em súditas (não, evidentemente, em cidadãs), mediante a criação de um estatuto jurídico de submissão e menoridade política. A questão parece ter se complicado porque os indígenas desfrutaram de um considerável grau de autonomia, jogando com os conflitos entre holandeses, portugueses e espanhóis até o século XIX, e entre ingleses e brasileiros até o começo do século XX. E sobretudo porque aquilo que parecia aos colonizadores uma ação civilizadora, pensada num primeiro momento como cristianização e mais tarde como pedagogia destinada a bárbaros, era visto pelos indígenas como um mosaico de alianças — das quais também faziam parte as relações de amizade e inimizade entre os povos indígenas.

A região visitada por Koch-Grünberg tinha assim uma história de guerras coloniais mais ou menos veladas e estratégias políticas, as quais visavam à estabilização de um território sob o manto de uma soberania específica. Se o antropólogo lá esteve entre 1911 e 1913, vale notar que (obviamente naquilo que concernia a ingleses e brasileiros) apenas em 1904 as fronteiras de Roraima com a Guiana inglesa foram delimitadas. Vinte e quatro anos antes de Macunaíma aparecer como "herói de nossa gente", o mato virgem estava em pleno litígio colonial. Além disso, se Koch-Grünberg lá esteve como cientista, a região já vinha sendo visitada, descrita e estudada por burocratas, missionários, enfim, uma série de escritores que tinham relações bem mais evidentes com as guerras coloniais. Sendo assim, o próprio estatuto dado a indígenas como povos "naturais", sem lei nem rei, fazia parte da disputa territorial. E, ao invés do quadro da natureza sublime, para além do histórico, o que temos é uma situação de grande complexidade política. ${ }^{23}$

Ao falar da etimologia de Makunaima, "o grande mau”, o antropólogo alemão aludiu ao fato de os missionários ingleses, em suas traduções da Bí- 
blia para os Arawoio, usarem Makunaima como termo equivalente para o deus cristão. A equivalência era possível porque Makunaima, em alguns dos relatos indígenas, funcionava como uma espécie de demiurgo - aspecto também aproveitado para a caracterização de Macunaíma na rapsódia de Mário de Andrade, como um herói que aqui e ali semeava alguns dos lugares-comuns da brasilidade, criando gestos, palavras e costumes. A situação histórica de Mário e dos missionários ingleses era, obviamente, bastante diversa, mas eles tiveram um solo comum que tornava possível ao poeta paulista, e a seus leitores, ler em Makunaima uma alegoria possível para a condição nacional brasileira, num trabalho de tradução que correspondia, de fato, a uma forma de apropriação.

Podemos, agora, retornar à questão central deste artigo: a estetização da natureza como resposta romântica a conflitos políticos específicos. A projeção de uma origem anterior à história para o herói que encarnaria as potencialidades da cultura nacional em formação deu-se a partir de um dispositivo estético de diluição do histórico no natural romântico. O espaço do mato virgem não é Roraima, mas ao mesmo tempo extraiu sua força poética e seu poder de convencimento de histórias que ali se desenrolaram. Estamos, assim, diante de uma relação metafórica que tem como resultante a naturalização da história. Que esta tenha se dado como denegação da violência e dos conflitos na estratégia conciliadora da colonização, eis aí o que parece fundamentar o sucesso da dis-solução macunaímica.

O nome Uraricoera pode ter sido escolhido por causa de sua sonoridade, de seu teor misterioso e exótico e assim por confluir para a invenção literária do espaço mágico do mato virgem, buscado por tantos viajantes desde o século XIX. Mas será que a literatura funciona como uma barragem entre o Uraricoera palco das disputas coloniais e o Uraricoera signo mágico da brasilidade? O propósito de apropriação territorial ligado ao estabelecimento do Estado-nação nada diria sobre a apropriação do texto literário, que fez nascer um mito nacional numa região forçadamente nacionalizada? Se o mito literário Macunaíma é projetado no não-histórico, o mito dos narradores indígenas, e sua coleta e catalogação intelectual, têm rastros que certamente são históricos. Há aqui um trânsito simplesmente denegado quando se acredita na autonomia da obra literária, na sua inteireza. Como se o charme de $\mathrm{Macu}$ naíma não viesse exatamente do fato de ser uma obra alimentada por dados etnográficos...

Edward Said ${ }^{24}$ tem uma sugestão interessante, a de que as tessituras ficcionais do imaginário geográfico dialogam com os projetos políticos de apro- 
priação do espaço. Notando a extrema mobilidade das personagens da literatura inglesa do período colonial, quando os mundos narrados remetiam às áreas colonizadas, Said não tratou o espaço narrativo como imitação da realidade, mas como seu duplo, no sentido de que a mobilidade tinha como contrapartida uma idéia de propriedade territorial. Entre o imaginário construído pela literatura sobre viajantes dotados da capacidade de explorar sem impedimentos as mais diversas regiões do mundo e o poder colonial propriamente dito tecia-se uma rede de significados próprios aos projetos de colonização. O imaginário ficcionalizado pela literatura, nestes casos, continuaria a luta pela apropriação territorial.

No caso brasileiro, essa questão é delicada ao ponto de declararmos que, qualquer que fosse o mito indígena escolhido pelo poeta, e qualquer que fosse o rio indicado, do Oiapoque ao Chuí, permaneceria a tensão entre as imagens das origens e da natureza tropical sublime e a seqüência das guerras coloniais que tentaram suprimir historicamente tudo o que era tido como obstáculo à unidade nacional. Claro, isso no caso da permanência do registro romântico. E o interesse disso não reside, apenas, num problema mais estritamente poético, uma vez que os textos considerados modernistas, e entre eles mais especificamente o Macunaíma, são constantemente retomados, citados, parafraseados exatamente por seu sentido supostamente revelador das profundezas da nacionalidade. O mato virgem projetado na narrativa seria então uma espécie de ilha de silêncio cercada por discursos por todos os lados.

Aliás, aqui se trata de um problema que era e continua sendo considerado obstáculo à soberania nacional, ao menos por alguns setores da opinião pública. Afinal (apenas como exemplo da atualidade da discussão em pauta) o atual presidente da Câmara dos Deputados, Aldo Rebelo, recentemente defendeu, juntamente com militares e arrozeiros de Roraima, a tese de que a delimitação contínua da Raposa/Serra do Sol representaria uma ameaça à defesa do território nacional. ${ }^{25} \mathrm{~A}$ imagem, talvez com certa dose de perspicácia (mas sob o pressuposto da crença na necessidade da integridade do Estadonação), é a dos indígenas mal integrados à nação fazendo alianças com agentes internacionais. Note-se que o mesmo deputado, em seu discurso de posse da referida presidência, aludiu à "grande civilização tropical" brasileira, referindo-se a Gilberto Freyre como mestre na arte da conciliação - o que ainda reforça a proximidade aqui apontada entre um ideário construído para a nação e determinadas projeções políticas.

Mas a unidade ameaçada também pode ser pensada no sentido do congraçamento hierárquico do mosaico das raças. Nas recentes discussões sobre 
as cotas para as universidades, por exemplo, o modernismo vem sendo evocado como produtor da resposta mais adequada aos conflitos raciais - aqui numa linha de discussão mais acadêmica e afinada com a sofisticação intelectual de Mário de Andrade. ${ }^{26}$ Independentemente do mérito da política das cotas, o que está em pauta aqui é a eficácia de uma solução que passa pela estetização do estado natural que teria posto no horizonte da nação a possibilidade de harmonia última. Não se tratando de discutir o Macunaíma de Mário de Andrade como uma espécie de falácia, o que aqui se pretende deslindar é a razão de sua eficácia política, ou o desejo de natureza próprio ao romantismo como uma resposta aos conflitos de nosso tempo.

\section{CONSIDERAÇÕES FINAIS}

Macunaíma, na rapsódia de Mário de Andrade, foi Imperador do Mato Virgem e filho do silêncio. Mas quando a rapsódia Macunaíma é mobilizada como resposta aos conflitos instaurados pela convivência do Estado nacional com os narradores indígenas de Makunaima, o silêncio se transmuta em silenciamento. A diferença entre silêncio e silenciamento está no fato de o segundo corresponder a uma atitude, uma intencionalidade (ainda que não "voluntária”), e o silêncio ser uma condição dada. No mesmo passo, a natureza desejada pela imaginação romântica se converte em naturalização da história.

Fazendo uma reflexão sobre minha trajetória (e apenas porque acredito que ela faça parte da trama histórica que aqui apresento, correspondendo a uma experiência compartilhada com outros pesquisadores) me pergunto por que somente recentemente tive como preocupação entender os fios que ligam e separam o Uraricoera do Uraricoera e Macunaíma de Makunaima. E não me refiro aqui à questão teórica da intertextualidade ou da paródia bakhtiniana, porque estas já foram repisadas pela crítica literária. ${ }^{27}$ Penso em relações mais concretas que ignoramos, apesar de estudarmos a obra de Mário de Andrade há tantos anos, e sabermos desde sua publicação que ela dialogava com certo relato etnográfico - e de termos, ao menos os mais dedicados à sua obra, logo lido a tradução de Koch-Grünberg na Revista do Museu Paulista. Desde os bancos escolares, mais recentemente, aprendemos que Mário de Andrade foi um grande estudioso da realidade nacional, e que ler suas obras seria uma das melhores chaves para a interpretação da brasilidade. Mas uma parte da dita realidade foi sonegada, encoberta pela beleza e sedução de um texto que apresenta uma natureza imune aos males da civilização. 
No final da rapsódia de Mário de Andrade, um Macunaíma derrotado na passagem da natureza à civilização desiste da vida neste mundo e se torna a constelação da Ursa Maior. Em explicação a Manuel Bandeira, Mário diria que tal constelação seria visível em todo o território nacional. A opção de Macunaíma corresponderia ainda a seu caráter desorganizado, à constante incapacidade do herói em tomar as rédeas de seu destino. Longe de ser um brilho inútil, porém, a Ursa Maior ganhava no texto uma rica sobreposição de sentidos: a promessa da magia natural do mato virgem, a advertência à brasilidade no sentido de que não se deixasse levar pelo caos da civilização.

Na década de 1990, o antropólogo Paulo Santilli ${ }^{28}$ ouviu do Sr. Leonardo, um macuxi, uma história em que brancos apareciam como apresadores de seus antepassados. Numa relação simbólica com as migrações forçadas e o trabalho compulsório que marcaram o contato dos macuxi com portugueses e brasileiros "às margens do Uraricoera", os brancos apresadores eram comedores de gente. Na narrativa de Leonardo, o xamã Jasmim consegue escapar dos colonizadores antropófagos subindo ao céu e se metamorfoseando em estrela cadente, para voltar para sua casa. A estrela cadente passa no céu como um vestígio ligeiro, e corresponde mais ao desejo de invisibilidade daquele que quer evitar um encontro funesto.

\section{NOTAS}

${ }^{1}$ ANDRADE, Oswald. Poesias reunidas. Rio de Janeiro: Civilização Brasileira, 1971. p.67-71.

${ }^{2} \mathrm{O}$ tema das viagens modernistas e das projeções da nacionalidade foi discutido em minha dissertação de mestrado, $O$ modernismo que se tornou romântico: literatura, política e brasilidade, defendida em 1999 na Universidade de Brasília.

${ }^{3}$ Cf. Formação da literatura brasileira. v.2. São Paulo: Martins, s.d. p.55-67.

${ }^{4}$ Para essa discussão, remeto a: NAXARA, Márcia. Cientificismo e sensibilidade romântica. Em busca de um sentido explicativo para o Brasil no século XIX. Brasília: Ed. UnB, 2004.

${ }^{5}$ Consulte-se, de preferência, a edição fac-similar de seus livros, lançada pela Imesp em 1982, uma vez que os textos têm imensa riqueza gráfica.

${ }^{6}$ Editora mantida pelo grupo de Plínio Salgado e Menotti del Picchia.

${ }^{7}$ Em: MORAES, Marcos Antônio de (Org.) Correspondência. São Paulo: Edusp, 2000. p.341.

${ }^{8}$ ANDRADE, Mário de. O turista aprendiz. São Paulo: Duas Cidades, 1983. p.61.

${ }^{9}$ Em: Modernismo reacionário. Tecnologia, cultura e política em Weimar e no Terceiro Reich. Campinas: Ed. Unicamp, 1993. p.49ss. 
${ }^{10}$ Consulte-se a carta publicada em: Correspondência, op. cit., "24 de março de 1926”, p.282.

${ }^{11}$ O turista aprendiz, op. cit., p.158.

${ }^{12}$ Uma crítica inspiradora a este lugar-comum da tradição interpretativa sobre o Brasil encontra-se em: BRESCIANI, Maria Stella. O charme da ciência e a sedução da objetividade. Oliveira Vianna entre intérpretes do Brasil. São Paulo: Ed. Unesp, 2005.

${ }^{13}$ Para Sérgio Buarque de Holanda, por exemplo, Macunaíma era, ao lado de Cobra Norato de Raul Bopp, a representação literária mais sugestiva do "substractum primitivo de nossa cultura". Em: "O Mito de Macunaíma". O Espírito e a letra. Estudos de crítica literária, 19201947. São Paulo: Companhia das Letras, 1996. p.260. O artigo foi originalmente publicado na revista $O$ Espelho, em 1935.

${ }^{14}$ Cf. Macunaíma. O herói sem nenhum caráter. (Edição crítica de Telê Porto Ancona Lopez). Rio de Janeiro: Livros Técnicos e Científicos; São Paulo: Secretaria da Cultura, Ciência e Tecnologia, 1978.

${ }^{15}$ Ver: BATISTA, Marta Rosseti et al. Brasil: $1^{\circ}$ Tempo Modernista — 1917/1929. São Paulo: IEB, 1972. p.289-95.

${ }^{16}$ Ibidem, p.291.

${ }^{17}$ Por isso, a obra perfaz um "mapeamento" do território brasileiro, em sentido similar ao realizado por Gonçalves de Magalhães, em 1841, identificado, por Flora Süssekind, com a consolidação da política imperial. Em: "Palavras loucas, orelhas moucas. Os relatos de viagem dos românticos brasileiros", Revista USP, n.30, jun.-ago. 1996, p.94-107.

${ }^{18}$ A obra de Rosset é marcada por um intuito claramente polêmico. Tomo-a, aqui, apenas como motivadora de algumas inspirações. A anti-natureza. Elementos para uma filosofia trágica. Rio de Janeiro: Espaço e Tempo, 1989.

${ }^{19} \mathrm{O}$ sentido pedagógico da estética e da política de Mário de Andrade foi um dos temas centrais de minha tese de doutorado, O mito modernista, defendida na Unicamp em 2004.

${ }^{20}$ A notação com a letra "k" marca a diferença entre as duas personagens. Além disso, pelo menos o Makunaima falado pelos macuxi vem com um ditongo, ao invés de um hiato entre o "a" e o "i”. Makunaima é personagem de uma rica tradição narrativa, compartilhada por diversos povos indígenas da bacia do Rio Branco, como os Taulepangue e Arekuná estudados por Koch-Grünberg, pertencentes à família lingüística karib.

${ }^{21}$ Para a escrita deste artigo, recorri à reedição de parte do texto de Koch-Grünberg (que na verdade retomou a tradução apresentada em 1953 na Revista do Museu Paulista). Cf. MEDEIROS, Sérgio (Org.) Makunaíma e Jurupari. Cosmogonias ameríndias. São Paulo: Perspectiva, 2002. A obra do antropólogo alemão, Von Roroima zum Orinoco. Ergebnisse einer Reise in Nordbrasilien und Venezuela in den Jahren 1911-1913, saiu originalmente em três volumes, publicados em 1916, 1917 e 1923. 
${ }^{22}$ Em: As muralhas dos sertões. Os povos indígenas no rio Branco e a colonização. Rio de Janeiro: Paz e Terra, 1991.

${ }^{23}$ Não tenho a pretensão de dar conta de tal complexidade. Aos interessados, sugiro a leitura de: SANTILLI, Paulo. As fronteiras da república. História e política entre os macuxi no vale do rio Branco. São Paulo: NHII-USP/Fapesp, 1994.

${ }^{24}$ Em: Cultura e imperialismo. São Paulo: Companhia das Letras, 1995. Sem procurar estabelecer uma causalidade simplista entre o literário e o político, Said intenta demonstrar como a imaginação geográfica de romancistas do período, como Eliot e Kipling, tinha como base a expansão político-econômica inglesa. Assim, por exemplo, a mobilidade de Kim, da autoria de Kipling, pelas terras da Índia seria, também, uma afirmação de posse.

${ }^{25}$ Indico, como exemplo, o artigo "Índio quer terra, se não der, pau vai comer", publicado em Isto é Dinheiro a 21.04.2004. O artigo faz referências às opiniões de Aldo Rebelo.

${ }^{26}$ Cf. MAGGIE, Yvonne. "Mário de Andrade ainda vive? O ideário modernista em questão”. Revista Brasileira de Ciências Sociais, v.20, n.58, jun. 2005.

${ }^{27}$ Fugindo aos lugares-comuns da dita crítica literária, uma das fontes de inspiração para a escrita deste artigo foi: HARDMAN, Francisco Foot. "Algumas fantasias de Brasil: o modernismo paulista e a nova naturalidade da nação". In: DEDECCA, Edgar; LEMAIRE, Ria (Org.) Pelas margens. Outros caminhos da história e da literatura. Campinas: Ed. Unicamp; Porto Alegre: Ed. UFRGS, 2000. p.317-32.

28 “Trabalho escravo e brancos canibais. Uma narrativa histórica macuxi”. In: RAMOS, Alcida Rita; ALBERT, Bruce (Org.) Pacificando o branco. Cosmologias do contato no NorteAmazônico. São Paulo: Ed. Unesp, 2002. p.487-506. 